\title{
INTERDEPENDENT ANALYSIS OF LEVERAGE, DIVIDEND, AND MANAGERIAL OWNERSHIP POLICIES Agencies Perspectives
}

\section{Wibisono Hardjopranoto*}

This paper attempts to investigate interdependent mechanism among leverage, dividend, and managerial ownership policies. This paper considers firm size and economic conditions to control their effect on the relationship among the three policies. The interrelationship between leverage, dividend, and managerial ownership policies will be tested using two-stage least squares. Five exogenous variables are employed in simultaneous equation: current assets and structure of assets as leverage determinants, book to market and return on investment as dividend determinants, and relative return to risk as managerial ownership determinant. The research employs year 1994-2004 data, with 1717 firm years. The research findings can be summarised as follows. First, there is a negative relationship between managerial ownership and leverage policies as suggested byagency theory. Second, there is a relationship between managerial ownership and dividend policies, but the relationship between leverage and dividend is insignificant. Third, the relationship between leverage and dividend is insensitive to economic condition and firm size. Fourth, all exogenous variables have significant effect on endogenous variables, except relative return. Fifth, the effects of exogenous variables are not sensitive to control variables. Sixth, we find that managers show self-interest behaviours by reducing managerial ownership when the economic condition worsens.

Keywords: dividend; interdependent mechanism, leverage, managerial ownership

* The author would like to thank Professor Eduardus Tandelilin for his invaluable comments, insights, and financial data sharing. 
Gadjah Mada International Journal of Business, May-August 2006, Vol. 8, No. 2

\section{Background}

Jensen and Meckling - (1976) define a company as a locus of contract or a number of contracts between an agent and a principal caused by the separation of ownership and control. Contract system tends to create moral hazard. The moral hazard occurs when the agent is able to undertake actions that cannot be controlled by the principal. An increase in leverage or debt is one of the alternatives to shift the monitoring costs from the principal to bondholders. The use of debt also pushes managers to be more discipline so as to shun bankruptcy (Harris and Raviv 1990). Debt also functions as a bonding means to management (Megginson 1997: 335).

This study discusses the interdependence of dividend, leverage, and managerial ownership policies. Agency cost of equity is difficult to observe directly; hence, variables of dividend and leverage policies that consider the separation between managerial interests and shareholders' interests are used. The relationship between leverage and dividend is mathematically examined by DeAngelo and Masulis (1980), who find that leverage and dividend are relevant if there are taxes and not in equilibrium condition. Koch and Shenoy (1999) prove that there is interdependence between leverage policy and dividend policy that simultaneously and significantly influence future cash flows. Hartono (2000) finds that dividend policy is a mechanism to reduce debt policy.
The interdependence amongst the three policies (debt, dividend, and insider ownership) is researched by Jensen et al. (1992), finding that leverage policy and dividend policy do not influence insider ownership, whilst insider ownership influences financing and dividend decisions. Crutchley and Hansen (1989) harnesses agency theory and variables that influence leverage and dividend using three-stage reduced-form regression model. They find that managers utilize three policies (ownership, leverage, and dividend) to decrease the agency cost. This finding supports the agency theory that agency cost of equity and agency cost of debt can be managed and controlled optimally using the interdependence of leverage, dividend, and insider ownership policies. They also point out that managerial ownership is influenced by relative return.

Myers (1977) reveals that companies with high assets in place are inclined to use higher leverage as the assets in place are basically a sunk cost. Several studies show that assets in place, proxied by fixed assets, have a positive impact on leverage (Ferri and Jones 1979; Marsh 1982; Long and Malitz 1985; Friend and Lang 1988; and Jensen et al. 1992). Collateral hypothesis argues that fixed assets can function as a bailout, showing that a company has enough resources to fulfil its liabilities. Through current assets, collateral hypothesis is supported by perquisites hypothesis. Perquisites hypothesis proposed in this 
Hardjopranoto-Interdependent Analysis of Leverage, Dividend, and ManagerialOwnership Policies

research argues that current assets can be utilized by management to exert perquisite actions. Shareholders incurring loss due to these perquisite actions will exert bonding mechanism through leverage policy.

Free cash flow hypothesis has a relation to investment opportunities; the higher the investment opportunities, the higher is the internal cash flows to be used to finance or to realize the investment opportunities (Myers and Majluf 1984; Jensen 1986). Remaining profits used to pay dividends are smaller such that growing companies will pay low dividends (Jensen et al. 1992). This argument is contradictory with signalling hypothesis that argues that declining dividend reflects management's pessimism towards the company's prospect such that it is a negative signal. An increase in dividend is a positive signal since it shows managerial confidence on the company's prospect.

Difference in company size can influence the relationship amongst the three policies and variables. Some research shows that company size can function as a control variable to clarify the relationship amongst variables tested (Murphy 1985; Smith and Watts 1992). Difference in economic condition can also influence the managerial behavior in making decisions. The relationship amongst financial decision variables and their determinants can also change when the economic condition changes substantially. This study controls the company size effect and the change in economic condition by cutting off year 1997 as the beginning period of financial crisis in Indonesia.

Predicated upon the discussion above, the research questions can be formulated as follows:

1. Is there a relationship amongst leverage, dividend, and managerial ownership policies?

2. Do current assets and fixed assets positively influence leverage?

3. Do investment opportunities and profitability influence dividend policy?

4. Does relative return influence managerial ownership?

General description on the agency problem in determining leverage, dividend, and managerial ownership policies is still an interesting issue to research. Some studies have yet to show results fully supporting the prediction of agency theory. The issue of agency conflict is valuable and worth to analyst as La Porta et al. (2000a) argue that ownership structure has suitable control over agency conflict. Ownership structure has a significant impact on reducing agency conflict especially in developing countries (e.g., Indonesia). Indonesian capital market is renown as a market with concentrated ownership structure. Baker and Wurgler (2004) test the effectiveness of dividend to control agency conflict. They find that dividend has a significant impact on reducing agency conflict between agent and principal. Indonesia experiences low dividend payment for listed firms (Mahadwartha 
2004). The phenomenon suggests that the agency conflict is lower in countries with high dividend payment, as Baker and Wurgler (2004) examine using United States data.

This research's finding is expected to contribute to empirical and policy aspects. Empirical contribution of this study is expected to support the agency theory, especially in explaining leverage, dividend, and managerial ownership policies to reduce agency conflict. The finding is also expected to provide additional explanations on the agency theory since it involves two panel data in the periods of normal economy and of economic crisis. Sensitivity testing model on the change in economic condition will elaborate on whether there is a difference in managerial behavior reflected by leverage, dividend, and managerial ownership policies in the different economic conditions.

Meanwhile, the policy contribution of this study is intertwined with its provision of literature and practice background and reference to decision makers, both companies and investors. It is expected that managers and investors understand the explanation of the agency relationship. Shareholders policy with respect to stock investment in firms should concern the agency conflict between managers and shareholders. Shareholders will justify that financial policies such as dividend and leverage are better control mechanisms for the agency conflict.
Managers offering ownership compensation scheme will consider their wealth more correlated with firm wealth and accordingly will be concerned with the firm value. Their interests should align with shareholders' interests so as to reduce the agency conflict.

\section{Literatures Review and Hypotheses Development}

The interdependence amongst leverage, dividend, and managerial ownership policies in agency theory perspective is included in behavioral research since it explains the effect of managerial behaviors and shareholders' behaviors on corporate financial decisions. The research is directed towards positivist agency theory as it examines the agency relationship between management or agent and shareholders or principal (Eisenhardt 1989).

\section{Interdependence of Leverage Policy and Managerial Ownership}

Managerial ownership policy is included into remuneration policy purporting to reduce the agency conflict between management and shareholders. Murphy (1985); Brickley et al. (1988); Jensen and Murphy (1990); and Smith and Watts (1992) explain how fixed compensation package (salary) and contingent package (bonuses and options) can be utilized as a means to align the managerial interests and 
Hardjopranoto-Interdependent Analysis of Leverage, Dividend, and ManagerialOwnership Policies

the shareholders' interests. ${ }^{1}$ Megginson (1997: 335) uses the term "bonding mechanism" that tries to align the interests of shareholders and those of management through programs that tie the personal wealth into the wealth of the company.

Management has lower risk aversion level than shareholders have since management is faced with high risk of losing jobs if the company finds difficulties in its operations. Meanwhile, shareholders can diversify their portfolios to reduce risk (Megginson 1997: 19). If the company risk increases, for instance the risk of financial distress, management may lose their jobs whilst shareholders who are well diversified will be faced with lower risk of financial distress.

This phenomenon leads to management more focusing on total risk of the company whilst shareholders are more concerned with market risk or beta since the firm specific risk has disappeared due to diversification. This risk phenomenon then possibly results in ambiguous research findings on remuneration (managerial ownership) in relation to leverage. Leland and Pyle (1977) and Kim and Sorenson (1986) find that the relationship between leverage and managerial ownership is positive. On the other hand, the research of Friend and Lang (1988), and Jensen et al. (1992) find a negative relationship between leverage and managerial ownership.
Leland and Pyle (1977) use the "signalling" argument that the leverage of company that has managerial ownership is a signal that the leverage is truly utilized for investment and increasing value of the company. Kim and Sorensen (1986) use demand-supply hypothesis, arguing that a company will increase leverage since insiders (management) are able to control the company more effectively by managerial ownership program. The program shifts the attention of management to risk towards market risk although their main concern is still on total risk. It purports to align the perspective on risk of management and of shareholders. Hence, a company having managerial ownership will employ higher leverage such that the relationship between managerial ownership and leverage is positive.

The studies of Leland and Pyle (1977), and Kim and Sorensen (1986) can be countered by the argument that management has possibly diversified their personal portfolios prior to deciding to buy the stocks of the company where they work. This argument considers that like investors and shareholders, management are also individuals able to invest their wealth. The argument is supported by Crutchley and Hansen (1989) finding that managers will proceed to own the company stocks if the stocks are approaching the efficient market line such that the diversification loss due to buying

\footnotetext{
${ }^{1}$ Jensen and Murphy (1990) uses the term "incentives" for fixed package and "insurance" for contingent compensation. Included in option-related package is managerial ownership program.
} 
Gadjah Mada InternationalJournal of Business, May-August 2006, Vol. 8, No. 2

their own company's stocks declines. If managers pay high attention to the diversification loss, it means that the managers have diversified their personal wealth.

Other empirical results contradicting with Leland and Pyle (1977) and Kim and Sorensen (1986) are Friend and Lang (1988), Jensen et al. (1992), Mahadwartha and Hartono (2002), Ismiyanti and Hanafi (2004), and Mahadwartha and Ismiyanti (2006) who find that leverage policy is negatively influenced by ownership structure. Increasing managerial ownership will lead to a stronger tie between management personal wealth and the company wealth; consequently, the management will strive for reducing the risks of losing job and personal wealth by decreasing debt which also means decreasing the company's financial risk.

The prevalence of financial distress arouses agency conflict through asset substitution and underinvestment (Copeland and Weston 1992: 332), meaning that managerial ownership is related to bankruptcy risk triggered by leverage. If the leverage is low, the company will increasingly hinge on equity financing, either by right issue or by managerial ownership, such that leverage negatively influences managerial ownership.

$H_{l}$ : The relationship of managerial ownership to leverage is negative.

\section{Interdependence of Dividend Policy and Managerial Ownership}

Dividend payment will prevent management from undertaking perquisite actions since the internal cash flows will be utilized to deliver dividends to stockholders (bonding mechanism). Companies that have a control mechanism and broad ownership structure are usually big companies that tend to pay dividends to alleviate the agency conflict between management and stockholders. In contrast, small companies with centered ownership structure on several individuals will pay out low dividends as the potential agency conflict is also low (Megginson 1997: $375){ }^{2}$ Hence, size variable is of importance in controlling the impact of dividend on managerial ownership, and vice versa.

In relation to $\mathrm{H}_{1}$, if the managerial ownership increases, it will lower leverage so that in order to finance investments, management will be dependent on retained earnings which also means reducing dividend. Jensen et al. (1992); Rozeff (1982); Mahadwartha and Hartono (2002), and Ismiyanti and Hanafi (2004) find that dividend policy is influenced by ownership structure in a negative relationship.

Dividend payment will decrease asymmetric information in a company. However, if the company has manage-

\footnotetext{
${ }^{2}$ The explanation on company size as a control variable is discussed in the research method section.
} 
Hardjopranoto-Interdependent Analysis of Leverage, Dividend, and ManagerialOwnership Policies

rial ownership program, the asymmetric information will automatically decline. This condition renders dividend payment irrelevant to be harnessed to reduce the asymmetric information (Megginson 1997: 373). ${ }^{3}$

$\mathrm{H}_{2}$ : Relationship of managerial ownership to dividend is negative.

The existence of managerial ownership leads signalling hypothesis to be less adequate to elaborate on the influence of dividend policy on the company value. Agency theory will be more robust to explain the phenomenon of dividend policy as a means to reduce asymmetric information that causes agency conflict between management and stockholders.

\section{Interdependence between Leverage Policy and Dividend Policy}

The explanation of agency theory in the relationship between dividend and leverage, and the relationship between leverage and dividend, is provided through free cash flow hypothesis (contracting model of dividend) and balancing model of agency cost. Free cash flow hypothesis (contracting model of dividend) predicts that dividend influences leverage in a positive direction (Megginson 1997: 362). A company delivering dividends in big amount will need additional funds through leverage to finance its investments such that the dividend policy influences the leverage policy in one direction (Emery and Finnerty 1997: 568). The company's internal cash is utilized to pay dividends so that it needs additional external funds through debt (free cash flow hypothesis).

The argument of Emery and Finnerty is substantiated by Miller and Rock (1985) in their conceptual article, revealing that high dividend payout is a signal of the company's increasing profitability in the future. Management gives the positive signal through the dividend payment such that investors recognize the future investment opportunities promising for the company value. Furthermore, high dividend payout means that in order to maintain its optimum capital structure, the company will employ higher debt to finance its investments (Emery and Finnerty 1997: 568; Easterbrook 1984).

Easterbrook (1984) also argues that stockholders will exert monitoring actions towards management; nevertheless, if the monitoring costs are high, they will harness the third party (debtholders or bondholders) for helping undertake the monitoring actions. Debtholders that have invested their money in the company by themselves will strive for undertaking the control activities on the use of their funds. Monitoring mechanism is usually implemented through debt covenant mechanism.

Hartono (2000), Mahadwartha and Hartono (2002), and Ismiyanti and

\footnotetext{
${ }^{3}$ By itself contradicting with signalling hypothesis.
} 
Gadjah Mada InternationalJournal of Business, May-August 2006, Vol. 8, No. 2

Hanafi (2004) find that dividend policy influences a company's leverage policy in a positive relationship. However, Hartono (2000) also finds that the leverage policy has insignificant impact on the dividend policy. The dividend policy, based on Hartono's (2000) finding, is influenced by the company's accounting decision. This empirical evidence shows that the relationship of dividend with leverage is positive. $H_{3}$ : The relationship of dividend with leverage is positive.

Balancing model of agency cost explains the influence of leverage on dividend policy. This model of agency theory elaborates on the trade-off between agency cost of equity and agency cost of debt (Megginson 1997: 338). Leverage policy influences dividend policy in a negative relationship. A company with high leverage (high agency cost of debt) will try to alleviate its agency cost of debt by decreasing the use of debt, thus financing its investments by internal cash flows. Stockholders will give up the internal cash flows, previously paid out as dividends, to finance investments such that the agency cost of equity will increase corresponding with the decrease in the agency cost of debt. The relationship between leverage policy and dividend policy based on the balancing model of agency cost is negative.

Balancing model of agency cost, supported by the finding of Jensen et al. (1992), Mahadwartha 2004, and Ismiyanti and Hanafi (2004), posits that management will be faced with a trade-off between dividend payment and fixed charge of leverage; accordingly, the higher the leverage, the lower the dividends will be.

\section{Determinants of Leverage}

\section{Current Assets}

Companies possessing high degree of current assets (CA) will use higher leverage. It is argued that the current assets are the companies' bailouts that the companies will be able to fulfil their leverage. This collateral hypothesis is linked to the possibility that management harnesses the current assets for self-interests, especially cash and inventories. Agency theory postulates that the use of leverage may decline managerial perquisite capability such that the relationship of current assets with leverage is positive.

Some research such as that of Ferri and Jones (1979), Marsh (1982), Long and Malitz (1985), Friend and Lang (1988), and Jensen et al. (1992) find that current assets have a positive relationship with leverage. The current asset variable is also utilized to examine the perquisite hypothesis that leverage policy can be harnessed to prevent and suppress the managerial perquisite behaviors. Leverage variable used has separated managerial ownership from nonmanagerial ownership (outside shareholders ownership).

$H_{4}$ : The relationship of current assets with leverage is positive.

Asset Structure. Myers (1977) points out those assets in place are better financed by leverage as the assets in place have a characteristic of sunk 
Hardjopranoto-Interdependent Analysis of Leverage, Dividend, and ManagerialOwnership Policies

costs. The assets in place are reflected by property, plant, and equipment (at historical costs) or net fixed assets. The higher the proportion of assets in place in a company's total assets, the higher will be the tendency of using leverage. This argument is supported by Skinner (1993). Barton et al. (1989) also add inventories into the assets in place. Their empirical finding shows that asset structure measured by considering inventories has a weak positive effect on leverage. The assets in place also function as collateral such that the higher the value of collateral, the higher the company's capability of acquiring debt so as to increase leverage.

$H_{5}:$ The relationship of asset structure with leverage is positive.

\section{Determinants of Dividend}

\section{Investment Opportunities}

Future investments will highly influence the value of company. Myers (1977) reveals that the company value is derived from a combination of future assets and future investments. High investment opportunity set (IOS) leads to high growth of the company. Every company has different IOS, depending on specific assets owned (Kester 1986), the variation of cross-sectional specific investments such as human resources and capital, and historical investments that make barriers to the entrance of competitive forces (Smith and Watts 1992). The difference in
IOS leads to the difference in optimality of leverage and dividend policies.

IOS can not be directly observed; instead, it is calculated using proxies. There are several proxies for IOS, categorized into price-based, investmentbased, and variancemeasures. Kallapur and Trombley (1999) find that the price-based proxy for IOS is more dominant than the other proxies. This study uses book-to-market value of equity (price-based category) as it is considered the best proxy for IOS. Similar to the research of Kallapur and Trombley (1999), in this study, low level book-to-market value of equity indicates high growth of company.

Companies with high growth will be forced to choose between paying dividends and incurring capital expenditures related to the investment opportunities. Imperfect capital market ${ }^{4}$ creates a kind of competition between dividend policy and investment financing using internal cash flows. Agency theory predicts that high-growth companies will pay out high dividends since high growth firms especially in developing countries lack of investor's protection (La Porta et al. 2000b).

Then how about growth options? Management of a company with high growth options will have better information on the existence of growth options; hence, shareholders need to make such "luring offers" to management that the management gives the information on growth options for the shareholders' interests. Asymmetric infor-

${ }^{4}$ Often called capital market friction. 
Gadjah Mada International Journal of Business, May-August 2006, Vol. 8, No. 2

mation creates conflict such that the information needs alignment. Bonding strategy in this case is executed by linking growth option to the company value and dividend payment.

$H_{6}$ : The relationship between book to market value and dividend is positive.

\section{Profitability}

Jensen (1986) argues that excessive free cash flows will lead to management committing moral hazard. A firm with high profitability is potential to have high free cash flows if high investment opportunities do not exist. Therefore, the agency theory argues that outside shareholders push managers to pay higher dividends in the presence of higher firm profitability.

$H_{7}$ : The relationship between profitability and dividend is positive.

\section{Determinants of Managerial Ownership}

Management will buy more shares of the company where they work in if the relative return of the ownership is low. Relative return is the loss if an individual decides to add one share or more to her portfolio (Crutcley and Hansen 1989). As a share is more aligned to the capital market line, the share is said to have a low relative return, therefore is more attractive to be held. This research differs from Crutcley and Hansen (1989) in which they use risk premium approach to calculating diversification losses of a share.
In relation to managerial ownership in the presence of higher relative return, a manager will have more incentives to buy the shares of the company where she works in, i.e., the probability that the managerial ownership is undertaken will be higher.

$H_{8}$ : The relationship between the relativereturn and managerial ownership is positive.

\section{Research Methods}

The sample are manufacturing companies listed on the Jakarta Stock Exchange (JSX) with financial data and supporting data (returns, right issues, and ownership proportion) fully available for the sampleperiod of 19942004. The observation years total 1,717 observation years. This research uses pooling data method and excluded all companies that went public after 1996 and delisted firms.

The model is constructed using three endogenous variables: leverage, dividend and managerial ownership. The endogenous variables are:

a. Leverage (LEV): This research uses the ratio of the long-term liabilities to total liabilities as the proxy for leverage.

b. Dummy Dividend (DDIV): This research uses dummy variable; $\mathrm{DDIV}=1$ for the observation year that pays out dividend and DDIV $=0$, vice versa, for the proxy for dividend. Data that tend to be binomial cause bias if absolute figures are used for dividend (Mahadwartha 2002). 
c. Managerial ownership (DMOWN): This research uses dummy variable for managerial ownership due to the tendency of the data to be binomial. DMOWN= 1 for observation years which have a proportion of managerial ownership and $\mathrm{DMOWN}=0$, vice versa.

Five exogenous variables in firmspecific characteristics are:

a. Current Assets (CA): Different from the research of Jensen et al. (1992) that uses fixed assets in explaining leverage, this research uses liquid assets variable. Besides testing collateral hypothesis, it is also used to test perquisite hypothesis by linking liquid assets to management perquisite actions because liquid assets contain cash and supplies that can be manipulated by management in perquisite actions. CA variable uses log-linear measurement to decrease dispersion with other variables.

b. Asset Structure (AS): Asset structure variable is calculated by dividing net fixed assets from total assets. This approach is different from previous studies. Barton et al. (1989) add inventories to the net fixed assets, whilst Skinner (1993) uses market value as the denominator. Different measurement consideration in this study is based on some arguments. First, net fixed assets reflect assets that directly influence company operations. Second, inven- tory items fluctuate in short run, so it can be used as the collateral of debt in the long term.

c. Investment Opportunity Set (IOSBM): IOS variable uses bookto-market equity (BE/MVE). Based on the research of Kallapur and Trombley (1999), BE/MVE variable, as the most valid proxy, is used as a growth proxy. Moreover, BVE/ MVE is a growth proxy often used by researchers in finance (Gaver dan Gaver 1993). ${ }^{5}$ Low book-tomarket value of equity shows high growth of company.

d. Profitability uses return on investment measured from operation profit divided by total assets.

e. Relative Return (RR): uses average return ( 52 weeks) divided by annual standard deviation of return with weekly data

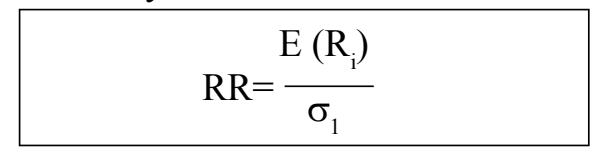

This research utilizes sensitivity test using two conditions: firm size and financial crisis. Firm size is a control variable, and it uses dummy variable. Size is measured by choosing the first 50 percent with null value of total asset ascended (DSIZE $=0$ ) and the low 60 percent with 1 value (DSIZE= 1). It is done to avoid bias effect on cross section in polling crosssectional data (Murphy 1985).

\footnotetext{
${ }^{5}$ The researchers are, amongst the others, Chung and Charoenwong (1991); Collins and Kothari
} (1989); Lewellen et al. (1987). 
Gadjah Mada InternationalJournal of Business, May-August 2006, Vol. 8, No. 2

The period of economic crisis in Indonesia uses dummy variable. Estimation period is divided into two subperiods from 1998 to 2004 with DCRS as the dummy variable for the period during the crisis. Period before crisis 1994-1997 is represented by the intercept. If DCRS is significant, so there is an intercept difference between and during the crisis periods. DCRS is expected to create more robust 3SLS estimation.

This researchuses three-stage least squares (3SLS) as the technical analysis. Endogenous, exogenous, and control variables for sensitivity test of regression function are:

a. Endogenous variables: Leverage (LEV), Dummy Dividend (DDIV), and Dummy Managerial Ownership (DMOWN).

b. Exogenous variables: Log-linear Liquid asset (LnCA), Asset Structure (AS), Investment Opportunities (IOSBM), Return on Investment (ROI) and Relative Return (RR).

c. Sensitivity test of control variable: Dummy Size (DSIZE) and Dummy Period Crisis (DC).

Research models are as follows:

$$
\begin{aligned}
\mathrm{LEV}_{\mathrm{it}}= & \alpha_{1}+\gamma_{11} \mathrm{DDIV}_{\mathrm{it}}+ \\
& \gamma_{12} \mathrm{DMOWN}_{\mathrm{it}}+ \\
& \beta_{13} \mathrm{LnCA}_{\mathrm{it}}+\beta_{14} \mathrm{AS}_{\mathrm{it}}+\varepsilon_{1} \\
\hline \hline \mathrm{DDIV}_{\mathrm{it}}= & \alpha_{2}+\gamma_{21} \mathrm{LEV}_{\mathrm{it}}+ \\
& \gamma_{22} \mathrm{DMOWN}_{\mathrm{it}}+ \\
& \beta_{23} \mathrm{IOSBM}_{\mathrm{it}}+\beta_{24} \mathrm{ROI}_{\mathrm{it}}+\varepsilon_{2}
\end{aligned}
$$

$$
\begin{aligned}
\operatorname{DMOWN}_{\mathrm{it}}= & \alpha_{3}+\gamma_{31} \mathrm{LEV}_{\mathrm{it}}+ \\
& \gamma_{32} \mathrm{DDIV}_{\mathrm{it}}+\beta_{33} \mathrm{RR}_{\mathrm{it}}+ \\
& \varepsilon_{3}
\end{aligned}
$$

\section{Research Findings}

Table 1 shows the description of research variables in the period before crisis 1994-1997 (DC =0) and the period during crisis 1998-2004 (DC = 1). Average leverage does not show substantial change, that is 27.88 percent in the period before crisis and 25.87 percent in the period during crisis. Average dividend shows a decrease in the period during crisis. Dividend decrease occurs since in the crisis period, most companies suffer from loss and hence do not have enough cash to pay dividends. This result is supported by the decrease in average return on investment (ROI measured from operation profit divided by total assets) in the period during crisis.

On the other hand, the average liquid asset rates ( $\mathrm{LnCA}$ ) and asset structure (SA) in both periods do not show any substantial changes. The average relative return (RR) shows quite big changes, from 27.86 percent in the period before crisis to 7.73 percent in the period during crisis.

Table 2 shows the interdependent analysis of leverage, dividend, and managerial ownership policies using three-stage least squares (3SLS). Simultaneous relationship between managerial ownership and leverage is 
Hardjopranoto-Interdependent Analysis of Leverage, Dividend, and ManagerialOwnership Policies

Table 1. Statistics Descriptive of Variables before and during Crisis Period

\begin{tabular}{|c|c|c|c|c|c|}
\hline & DC & $\mathbf{N}$ & Mean & Std. Dev & $\begin{array}{l}\text { Std. Error } \\
\text { Mean }\end{array}$ \\
\hline $\begin{array}{l}\text { Leverage } \\
(\mathrm{LEV})\end{array}$ & $\begin{array}{l}0 \\
1\end{array}$ & $\begin{array}{r}632 \\
1085\end{array}$ & $\begin{array}{l}0.2788 \\
0.2587\end{array}$ & $\begin{array}{l}0.2533 \\
0.3090\end{array}$ & $\begin{array}{l}0.0101 \\
0.0088\end{array}$ \\
\hline $\begin{array}{l}\text { Dummy Dividend } \\
\text { (DDIV) }\end{array}$ & $\begin{array}{l}0 \\
1\end{array}$ & $\begin{array}{r}632 \\
1085\end{array}$ & $\begin{array}{l}0.7832 \\
0.3278\end{array}$ & $\begin{array}{l}0.4124 \\
0.6785\end{array}$ & $\begin{array}{l}0.0164 \\
0.0145\end{array}$ \\
\hline $\begin{array}{l}\text { DummyManagerial Ownership } \\
\text { (DMOWN) }\end{array}$ & $\begin{array}{l}0 \\
1\end{array}$ & $\begin{array}{r}632 \\
1085\end{array}$ & $\begin{array}{l}0.1851 \\
0.1265\end{array}$ & $\begin{array}{l}0.3887 \\
0.3546\end{array}$ & $\begin{array}{l}0.0155 \\
0.0124\end{array}$ \\
\hline $\begin{array}{l}\text { Log-linier Current Assets } \\
\text { (LnCA) }\end{array}$ & $\begin{array}{l}0 \\
1\end{array}$ & $\begin{array}{r}632 \\
1085\end{array}$ & $\begin{array}{l}25.7543 \\
26.2987\end{array}$ & $\begin{array}{l}1.3521 \\
1.5089\end{array}$ & $\begin{array}{l}0.0538 \\
0.0589\end{array}$ \\
\hline $\begin{array}{l}\text { Asset Structure } \\
\text { (AS) }\end{array}$ & $\begin{array}{l}0 \\
1\end{array}$ & $\begin{array}{r}632 \\
1085\end{array}$ & $\begin{array}{l}0.3608 \\
0.3908\end{array}$ & $\begin{array}{l}0.1880 \\
0.3349\end{array}$ & $\begin{array}{l}0.0075 \\
0.0086\end{array}$ \\
\hline $\begin{array}{l}\text { Investment Opportunity Set } \\
\text { (IOSBM) }\end{array}$ & $\begin{array}{l}0 \\
1\end{array}$ & $\begin{array}{r}632 \\
1085\end{array}$ & $\begin{array}{l}1.6718 \\
0.0773\end{array}$ & $\begin{array}{l}2.4132 \\
0.9282\end{array}$ & $\begin{array}{l}0.0960 \\
0.0368\end{array}$ \\
\hline
\end{tabular}

Note: DC= dummy crisis; $1994-1997=$ before crisis; $1998-2004=$ during crisis

shown in Panel A and Panel C. Panel A shows that managerial ownership brings negative and significant effect on leverage, and the effect is higher than that of dividend on leverage. This result is consistent with the first research hypothesis that there is a negative relationship between managerial ownership and leverage.

Simultaneous relationship between managerial ownership and dividend is shown in Panel B and Panel C. Both panels show that the relationship between the two variables is positive and insignificant. This result fails to support the second hypothesis that there is a negative relationship of managerial ownership with dividend.

Panel A and B show simultaneous relationship between leverage policy and dividend policy. Both panels show that the relationship between the two variables is positive but insignificant. This result is in line with the third hypothesis prediction that there is a positive relationship between leverage policy and dividend policy, but the insignificance renders the result meaningless.

Panel A shows the effect of two exogenous variables, which are the determinants of leverage: current assets and asset structure. Both variables are evidenced to have positive and significant effect on leverage as predicted in the fourth and fifth hypotheses.

Panel B shows the effect of two exogenous variables, which are the determinants of dividend: book to market and return on investment that are proxies for investment opportuni- 
Gadjah Mada InternationalJournal of Business, May-August 2006, Vol. 8, No. 2

Table 2. Three-Stage Least Squares Analysis (Leverage, Dividend, and Managerial Ownership)

\begin{tabular}{|c|c|c|c|}
\hline Variable & Coefficient & t-Stat & Goodness of fit \\
\hline \multicolumn{4}{|c|}{ Panel A: Endogenous variable (leverage) } \\
\hline Constant & -0.8732 & $-2.4125 * *$ & $\mathrm{R}^{2}=0.1245$ \\
\hline DDIV & 0.0276 & 1.1365 & Adjusted $\mathrm{R}^{2}=0.1178$ \\
\hline DMOWN & -0.0523 & $-7.3239 * * *$ & \\
\hline LnCA & 0.0652 & $11.1871 * * *$ & \\
\hline AS & 0.3012 & $2.4933 * *$ & \\
\hline
\end{tabular}

Panel B: Endogenous variable (dividend)

\begin{tabular}{lccr} 
Constant & 0.2264 & $12.5332 * * *$ & $\mathrm{R}^{2}=0.1378$ \\
LEV & 0.0183 & 0.5239 & Adjusted $\mathrm{R}^{2}=0.1322$ \\
DMOWN & 0.2332 & 1.8675 & \\
IOSBM & 0.0447 & $3.4386^{* * *}$ & \\
ROI & 2.2985 & $12.8150^{* * *}$ & \\
\hline
\end{tabular}

Panel C: Endogenous variable (managerial ownership)

\begin{tabular}{lccr} 
Constant & 0.2273 & $5.2852 * * *$ & $\mathrm{R}^{2}=0.0419$ \\
LEV & -1.3274 & $-6.9710 * * *$ & Adjusted $\mathrm{R}^{2}=0.0382$ \\
DDIV & 0.0398 & 0.2373 & \\
RR & 0.0461 & 0.8456 & \\
\hline
\end{tabular}

Note: $*=0.10$ significant level; $* *=0,05$ significant level; $* * *=0,01$ significant level; $\mathrm{D}=$ dummy variable

ties and profitability. Both variables are proven to have positive and significant effect on dividend as predicted in the sixth and seventh hypotheses.

Panel C depicts the effect of exogenous variable, which is relative return on managerial ownership. The relative return variable has positive effect, albeit its insignificance, on managerial ownership. The positive effect of relative return is expected by the eight hypotheses. Nevertheless, the insignificant result does not cause the interpretation of this variable to be less crucial.
In general, the result of interdependent analysis of leverage, dividend, and managerial ownership yields a relatively moderate result. The mechanism of the relationship amongst endogenous variables is still partial in nature. The particular result requires further investigation to find out the sensitivity of the simultaneous model towards the effect of firm size and of economic condition whether in normal or crisis state.

Table 3 examines the sensitivity of the simultaneous model towards the effect of firm size and crisis period. 
Hardjopranoto-Interdependent Analysis of Leverage, Dividend, and ManagerialOwnership Policies

Table 3. Three-Stage Least Squares Analysis (Leverage, Dividend, and Managerial Ownership with Sensitivity Analysis to Firm Size and Crisis Period)

\begin{tabular}{|c|c|c|c|}
\hline Variable & Coefficient & t-Stat & Goodness of fit \\
\hline \multicolumn{4}{|c|}{ Panel A: Endogenous variable (leverage) } \\
\hline Constant & -0.1137 & -0.0047 & $\mathrm{R}^{2}=0.1379$ \\
\hline DDIV & 0.0150 & 1.1191 & Adjusted $\mathrm{R}^{2}=0.1303$ \\
\hline DMOWN & -0.2854 & $-3.6301 * * *$ & \\
\hline LnCA & 0.0295 & $2.5533 * *$ & \\
\hline AS & 0.2451 & $8.2382 * * *$ & \\
\hline DSIZE & 0.1640 & $2.7220 * *$ & \\
\hline DC & -0.0499 & $-2.8720 * *$ & \\
\hline
\end{tabular}

Panel B: Endogenous variable (dividend)

\begin{tabular}{lllr} 
Constant & 0.6971 & $5.5504 * * *$ & $\mathrm{R}^{2}=0.3240$ \\
LEV & 0.4926 & 0.5583 & Adjusted $\mathrm{R}^{2}=0.3145$ \\
DMOWN & 0.0337 & $2.4614 * *$ & \\
IOSBM & 0.0274 & $2.1856 * *$ & \\
ROI & 2.8862 & $7.5224 * * *$ & \\
DSIZE & -0.5620 & $-2.8867 * *$ & \\
DC & -0.4512 & $-9.6701 * * *$ & \\
\hline
\end{tabular}

Panel C: Endogenous variable (managerial ownership)

\begin{tabular}{lrcr} 
Constant & 0.5711 & $6.8387 * * *$ & $\mathrm{R}^{2}=0.0388$ \\
LEV & -0.2582 & $-4.0081 * * *$ & Adjusted $\mathrm{R}^{2}=0.0327$ \\
DDIV & 0.1930 & $2.4432 * *$ & \\
RR & 0.0205 & 1.0519 & \\
DSIZE & -0.0529 & -1.1576 & \\
DC & -0.0881 & $-6.8836 * * *$ & \\
\hline
\end{tabular}

Note: $*=0.10$ significant level; $* *=0,05$ significant level; $* * *=0,01$ significant level; $\mathrm{D}=$ dummy variable

Panel A, B and C show that substantial changes prevail in the linkage amongst research variables. The results in Table 3 relatively differ from those in Table 2 discussed in the previous section. Based on the particular result, it can be seen that the simultaneous model is also sensitive to the size of the firm and crisis period.
The interdependent relationship between managerial ownership and dividend, which is insignificant in Table 2, becomes significant and in line with prediction when firm size and crisis period are added. This is highly caused by the significant decease in managerial ownership before crisis period and likewise dividend. 
On the other hand, firm size effect is evidenced to have a negative influence on two equations: endogenous variables (significant) and managerial ownership (insignificant). Firm size positively and significantly influences leverage. It indicates that big companies are inclined to have higher debt compared to small companies. Dividend payouts of big companies are significantly lower than that of small companies. The level of managerial ownership is practically higher for big companies than for small companies, but this finding is not significant.

The effect of economic condition change is proven to significantly influence endogenous variables: leverage, dividend, and managerial ownership. This result indicates that leverage level used in the economic crisis period will be significantly lower than that in the normal period. This is mainly caused by the success of restructuring program done by government, banking sector, and creditors in suppressing the problematic companies' debts. Besides, the decrease in debt level is also triggered by declining investment opportunities in the crisis period. The dividend paid out in the crisis period is significantly lower than that paid out in the normal period. Likewise, managerial ownership in the crisis period is significantly lower than that in the normal period.

\section{Discussion and Implications}

This research finding shows that there is a negative relationship be- tween managerial ownership and leverage. A company with managerial ownership has a lower level of leverage compared with that without managerial ownership. The wealth of managers owning managerial ownership is strongly related to the company wealth. Risk of losing personal wealth will increase as the risk of company increases. One of the causes of risk is debt. Less debt will decrease the company risk, and so will the risk of managers' personal wealth. Less leverage is expected to decrease the bankruptcy risk and financial distress. Therefore, if the leverage is higher, management chance to have managerial ownership will be lower.

The result partially fails to test that there is a significant and negative relationship between managerial ownership and dividend. Managerial ownership does not affect dividend policy, and vice versa. Hence, the result is contradictory with Rozeff (1982); Jensen et al. (1992); and Mahadwartha and Hartono (2002), finding that dividend policy is affected by the company's ownership structure with a negative relationship. Higher managerial ownership will decrease leverage and it forces management to depend more on retained earnings (retention ratio is higher) to finance the investments that also tends to decrease dividend. The effect of dividend policy on managerial ownership is not significant either such that there is no simultaneous relationship between those policies. This result is on the contrary with Mahadwartha (2002) who finds 
Hardjopranoto-Interdependent Analysis of Leverage, Dividend, and ManagerialOwnership Policies

that dividend affects managerial ownership with a negative relationship.

The main rationale behind the fact is probably managers' inclination to take managerial ownership decision by considering risk factor more than profit factor (return from stock ownership). Managerial ownership does not have any substitution characteristic on dividend in decreasing the agency conflict. The result shows that managerial ownership plays a minor role in reducing agency conflict. Firms with low or high managerial ownership have indifferent impact on agency conflict. This result suggests that Indonesian firms have more concentrated ownership compared to that in other developing countries. Mahadwartha (2004) suggests that Indonesian firms are family-controlled firms. Hence, future research should be more focused on ultimate shareholders to control agency conflict in Indonesia. Unfortunately, ultimate shareholders data in Indonesia are difficult to access fully, if not unavailable.

The relationship between leverage and dividend with or without control variable is proved to be positive, but not significant. There are two theoretical explanations for this being on the contrary with agency theory prediction. First, pecking order theory assumes that dividend is sticky, so it does not have any effect on and is not affected by leverage policy. Leverage policy tends to fluctuate, depending on the need for funds of the company to invest.
The second is clientele effect. Investors have different preferences on dividend. Some investors prefer the company to pay high dividends whilst some prefer low dividend rate or event zero dividend. Clientele effect explains that the company will decide its dividend policy based on the investors' preferences, so the leverage policy does not influence or is not influenced by dividend policy.

Liquid assets variable tests the perquisite hypothesis that leverage policy can be used to suppress perquisite managerial actions using liquid assets because leverage variable is used to separate the ownership by management from that by nonmanagement (outside shareholders). Liquid assets affect leverage with a positive and significant relationship. Higher liquid assets lead to higher leverage level. Based on the agency theory prediction, the liquid assets are utilized to suppress managerial perquisite actions related with the ability to fulfil its obligations.

Collateral hypothesis is related to the management possibility to harness the liquid assets for their own businesses, especially cash and inventories. Asset structure is used as a guarantee of the company's obligations, thus higher asset structure leads to higher company's leverage level. Besides, agency theory suggests that the use of leverage will decrease management perquisite ability and hence make the relationship between liquid assets and leverage level positive. The rela- 
Gadjah Mada International Journal of Business, May-August 2006, Vol. 8, No.2

tionship between liquid assets and asset structure with positive leverage is based on the prediction of collateral and perquisite hypotheses.

The effect of book to market on dividend is positive and significant. Lower book to market means higher growth and lower dividend payment. Based on the free cash flow hypothesis, higher growth will enable the company to pay lower dividends because most of retained earnings are used for investments. Higher growth will decrease perquisite ability to exploit the company's cash flows. This result is supported by Jensen et al. (1992), also by Mahadwartha and Hartono (2002) who conclude that growing companies pay less dividends.

The relationship of return on investment is significantly positive to dividend. Higher company profit will also give higher dividend because shareholders will require higher return through dividend payment. Agency theory explains that an increase in profit will means higher cash flows, hence increasing management ability to take perquisite actions (Jensen 1986). Therefore, shareholders will apply a bonding mechanism through the increase in dividend.

The relationship of relative return to managerial ownership is positive, but not significant. This result shows that management does not consider stock relative return to hold the company's stocks. It is possibly because stock return is not able to compensate the management for the risk suffered from owning the stocks. Investors are suggested to avoid companies that have high leverage and do not have managerial ownership. Companies with high leverage tend not to have managerial ownership, reflecting high managerial expectation on the company risk. Investors having already invested in companies with high leverage can compensate for the high financial risk through the dividend payment.

Managers are suggested to avoid the use of high leverage because it will increase the financial risk. Managers that have managerial ownership in a company with high leverage tend to suffer from higher risk than do investors. It causes managers to have double risk. First, high leverage brings implications on higher company risk, and then decreasing the value of the company. It also means that the managers' personal wealth as the owners will decline. Second, a company with high leverage is faced with higher bankruptcy risk. It leads to higher management possibility to lose their jobs. The failure of managers to keep and develop the company will plunge their reputation in the labor market. 
Hardjopranoto-Interdependent Analysis of Leverage, Dividend, and ManagerialOwnership Policies

\section{References}

Ang, J., J. Chua, and J. McConnell. 1982. The administrative costs of corporate bankruptcy: A note. The Journal of Finance: 219-226.

Barton, S. L., N. C. Hill, and S. Sundaram. 1989. An empirical test of stakeholder theory prediction of capital structure. Financial Management (Spring): 36-44.

Baker, M., and J. Wurgler. 2004. Appearing and disappearing dividends: The link to catering incentives. Journal of Financial Economics 73: 271-288.

Brickley, J. A., R. C. Lease, and C. W. Smith. 1988. Ownership structure and voting on antitakeover amendments. Journal of Financial Economics 20: 267-291.

Chung K., and C. Charoenwong. 1991. Investment options, assets in place and the risk of stocks. Financial Management 20: 21-33.

Collins, D. W., and S. P. Kothari. 1989. An analysis of intertemporal and cross sectional determinants of earnings response coeficients. Journal of Accounting and Economics 11: $143-181$

Copeland, T. E., and J. F. Weston. 1992. Financial Theory and Corporate Policy ( $3^{\text {rd }}$ ed.). Addison-Wesley Publishing Company.

Crutchley, C. E., and R. S. Hansen. 1989. A test of the agency theory of managerial ownership, corporateleverage, and corporate dividends. Financial Management: $36-$ 46.

DeAngelo, H., and R. W. Masulis. 1980. Leverage and dividen irrelevancy under corporate and personal taxation. The Journal of Finance: 453-464.

Easterbrook, F. 1984. Two agency-cost explanations of dividend. American Economic Review: 650-659.

Eisenhardt, K. M. 1989. Agency theory: An assesment and review. Academy of Management Review: 57-74.

Emery, D.R., and J. D. Finnerty. 1997. Corporate Financial Management (International ed.). New Jersey: Prentice Hall Inc.

Ferri, M., and W. Jones. 1979. Determinants of financial structure: A new methodological approach. The Journal of Finance 34: 631-644.

Friend, I., and L. H. P. Lang. 1988. An empirical test of the impact of managerial selfinterest on corporate capital structure. The Journal of Finance 43: 271-282.

Gaver, J. J., and K. M. Gaver. 1993. Additional evidence on the association between the investment opportunity set and corporate financing, dividend, and compensation policies. Journal of Accounting and Economics: 125-160.

Harris, M., and A. Raviv. 1990. Capital structure and the information role of debt. The Journal of Finance (June): 321-349.

Hartono, J. 2000. An agency-cost explanation for dividend payments. Working Paper. Yogyakarta, Indonesia: Universitas Gadjah Mada. 
Gadjah Mada InternationalJournal of Business, May-August 2006, Vol. 8, No. 2

Ismiyanti, F., and M. M. Hanafi. 2004, Struktur kepemilikan, risiko, dan kebijakan keuangan: Analisis persamaan simultan. Jurnal Ekonomi dan Bisnis Indonesia. Yogyakarta, Indonesia: Faculty of Economics- Universitas Gadjah Mada.

Jensen M. C., and K. J. Murphy. 1990. Performance pay and top-management incentives. Journal of Political Economy 98 (2): 225-264.

Jensen, G. R., D. P. Solberg, and T. S. Zorn. 1992. Simultaneous determination of insider ownership, debt and dividend policies. Journal of Financial and Quantitative Analysis: 247-263.

Jensen, M. C. 1986. Agency cost and free cash flow, corporate finance, and takeovers. American Economics Review: 323-329.

Jensen, M. C., and W. H. Meckling. 1976. Theory of the firm: Managerial behavior agency costs and capital structure. Journal of Financial Economics: 305-360.

Kallapur, S., and M. A. Trombley. 1999. The association between investment opportunity set proxies and realized growth. Journal of Business Finance and Accounting 26: $505-$ 519.

Kim, S.W., and E.H. Sorensen (1986), "Evidence on The Impact of The Agency cost of debt on Corporate Debt Policy," Journal of Financial and Quantitative Analysis 21, 131-144.

Koch, P. D., and C. Shenoy. 1999. The information content of dividend and capital structure policies. Financial Management: 16-35.

Leland, H. E., and D. H. Pyle. 1977. Information asymmetries, financial structure, and financial intermediation. The Journal of Finance 32: 371-387.

Lewellen, W., C. Loderer, and K. Martin. 1987. Executive compensation contracts and executive incentive problems: An empirical analysis. Journal of Accounting and Economics 9: 287-310.

Long, M.S., and I. B. Malitz. 1985. Investment patterns and financial leverage. In National Bureau of Economic Research: Corporate Capital Structures in the United States edited by B.M. Friedman (ed): 325-348.

Mahadwartha, P. A., and H. M. Jogiyanto. 2002. Uji teori keagenan dalam hubungan interdependensi antara kebijakan hutang dengan kebijakan dividen. Simposium Nasional Akuntansi (5-6 September). Universitas Diponegoro, Semarang.

Mahadwartha, P. A. 2002. The association of managerial ownership with dividend policy and leverage policy: A logit model. Proceeding Simposium Surviving Strategies to Cope with The Future (September $13^{\text {th }}$ ). Atmajaya Yogyakarta University.

Mahadwartha, P.A. 2004. Pengawasan dan pengikatan berbasis kepemilikan institusional internal. Desertation (unpublished). Universitas Gadjah Mada.

Mahadwartha, P. A., and F. Ismiyanti. 2006. Debt policy, free cash flow hypothesis, and balancing of agency theory through ownership: Evidence from Indonesia. Journal of Corporate Ownership and Control 5 (1).

Marsh, P. 1982. The choice between debt and equity: An empirical study. The Journal of Finance 37: 121-144. 
Hardjopranoto-Interdependent Analysis of Leverage, Dividend, and ManagerialOwnership Policies

Megginson, W. L. 1997. Capital Structure Theory, Corporate Finance Theory. Reading Massachusetts: Addison-Wesley.

Miller, M., and K. Rock. 1985. Dividend policy under asymmetric information. The Journal of Finance: 1031-1052.

Murphy, K. J. 1985. Corporate performance and managerial remuniration: An Empirical Analysis," Journal of Accounting and Economics 7, 11-42.

Myers, S. C. 1977. The determinant of corporate borrowing. Journal of Financial Economics 5: 147-176.

Myers, S. C., and N. S. Majluf. 1984. Corporate financing and investment decisions when firms have information investors do not have. Journal of Financial Economics 13; 187-221.

Porta R. L., F. Lopez-De-Silanes, A. Shleifer, and R. W. Vishny. 2000a. Agency problems and dividend policies around the world. The Journal of Finance 55 (1): 1-33.

Porta R. L., F. Lopez-De-Silanes, A. Shleifer, and R. W. Vishny. 2000b. Investor protection and corporate governance. Journal of Financial Economics 58: 3-27

Ross, S., R. W. Westerfield and J. Jaffe. 1999. Corporate Finance ( $5^{\text {th }}$ ed.) Irwin: McGrawHill.

Rozeff, M. S. 1982. Growth, beta and agency costs as determinants of dividend payout ratios. Journal of Financial Research:249-259.

Skinner, D. J. 1993. The investment opportunity set and accounting procedure choice. Journal of Accounting and Economics 16: 407-445.

Smith Jr. C. W., and R. L. Watts. 1992. The Investment opportunity set and corporate financing, dividend, and compensation policies. Journal of Financial Economics 13: 187-221. 